\title{
REMOVAL COD DAN TSS LIMBAH CAIR RUMAH POTONG AYAM MENGGUNAKAN SISTEM BIOFILTER ANAEROB
}

\author{
Uswatun Hasanah $^{1)}$ dan Sugito ${ }^{1)}$ \\ 1) Program Studi Teknik Lingkungan, Fakultas Teknik Sipil dan Perencanaan (FTSP) \\ Universitas PGRI Adi Buana Surabaya. \\ Email: untsa_cute1@ymail.com
}

\begin{abstract}
Abstrak
Tingginya kandungan zat organik pada limbah cair industri rumah potong ayam (RPA) menyebabkan limbah cair tersebut tidak boleh dibuang langsung ke lingkungan akuatik. Peningkatan kebutuhan protein dari sumber konsumsi daging ayam, menyebabkan peningkatan limbah cair industri RPA. Oleh karena itu diperlukan suatu alternatif penyelesaian untuk menurunkan kandungan beban pencemar pada limbah cair industri RPA agar kualitas effluent yang dihasilkan tidak mencemari lingkungan serta memenuhi baku mutu yang telah ditetapkan. Pada penelitian ini pengolahan limbah cair RPA dilakukan dengan menggunakan sistem biofilter anaerob media bioball, dengan variasi waktu tinggal dan konsentrasi influnt. Sampel pengukuran konsentrasi Chemical Oxygen Demand (COD) influent berturut turut sebesar 734 $\mathrm{mg} / \mathrm{L}, 388 \mathrm{mg} / \mathrm{L}$, dan $248 \mathrm{mg} / \mathrm{L}$. Konsentrasi Total Suspended Solid (TSS) dalam air baku limbah RPA sebesar $88 \mathrm{mg} / \mathrm{L}, 70 \mathrm{mg} / \mathrm{L}$, dan $54 \mathrm{mg} / \mathrm{L}$. Setelah dilakukan pengolahan mengalami penurunan konsentrasi COD dan TSS terhadap semua variasi konsentrasi. Waktu tinggal yang paling efektif dalam menurunkan kadar COD dan TSS pada limbah cair RPA adalah 7 jam.
\end{abstract}

Kata Kunci: Biofilter Anaerob, Media Bioball, Limbah RPA, Baku Mutu Limbah.

\begin{abstract}
The high content of organic substances in chicken slaughterhouse industrial wastewater make the chicken slaughterhouse wastewater don't discharged directly into the aquatic environment. And with the increasing amount of chicken meat consumption, causing an increase in chicken slaughterhouse industrial wastewater. Therefore need an alternative settlement to reduce the content of pollutant load in chicken slaughterhouse wastewater that the quality of effluent produced does not pollute the environment and meet the quality standards that have been set. This observation process uses anaerobic biofilter system with bioball, which is done as an alternative treatment of chicken slaughterhouse industrial wastewater based on the variation of the detention time and influent concentrationt. The results of the measurement of the concentration of Chemical Oxygen Demand (COD) in the raw wastewater of $734 \mathrm{mg} / \mathrm{L}$, $388 \mathrm{mg} / \mathrm{L}$, and $248 \mathrm{mg} / \mathrm{L}$. While the concentration of Total Suspended Solid (TSS) in the raw wastewater by $88 \mathrm{mg} / \mathrm{L}, 70 \mathrm{mg} / \mathrm{L}$, and $54 \mathrm{mg} / \mathrm{L}$. After processing decreased COD and TSS concentrations against all variations of concentration. The detention time of the most effective in lowering levels of COD and TSS in chicken slaughterhouse wastewater is 7 hours.
\end{abstract}

Keyword: Anaerobic Biofilter, Bioball, Chicken Slaughterhouse Wastewater, Quality Standards of Wastewater 


\section{PENDAHULUAN}

Usaha rumah pemotongan ayam (RPA) di Indonesia telah menjadi sebuah industri yang memiliki komponen lengkap dari sektor hulu sampai ke hilir. Perkembangan usaha RPA memberikan kontribusi nyata dalam sektor ekonomi. Hal ini dikarenakan produk unggas, yakni daging ayam dan telur harganya relatif murah dan stabil sehingga dapat menjangkau masyarakat luas, (Singgih dan Kariana, 2008).

Peningkatan jumlah konsumsi daging ayam berdampak pada meningkatnya limbah yang dihasilkan industri RPA. Limbah yang dihasilkan industri RPA ada dua jenis, yaitu limbah padat berupa bulu, isi rumen dan kotoran hewan serta limbah cair bekas pencucian ayam yang bercampur dengan darah dan lemak (Al Kholif, 2015). Menurut Said (2005), limbah cair organik yang dihasilkan industri RPA memiliki parameter chemical oxygen demand (COD), serta kandungan zat organik yang sangat tinggi. Oleh karena itu pengolahan limbahnya harus baik, sehingga ketika dibuang langsung ke lingkungan akuatik tidak akan merusak lingkungan tersebut, termasuk biota yang hidup didalamnya.

Karakteristik parameter limbah cair RPA memiliki kandungan COD dan TSS yang cukup tinggi. Limbah cair RPA memiliki nilai COD sebesar 656 mg/L (Al Kholif, 2015), dan TSS sebesar $247 \mathrm{mg} / \mathrm{L}$ (Said dan Firli, 2005). Nilai parameter pencemar tersebut masih di atas baku mutu berdasarkan Pergub Jatim No. 72 Tahun 2013 yang mensyaratkan BOD5 $100 \mathrm{mg} / \mathrm{L}$, COD $200 \mathrm{mg} / \mathrm{L}$, TSS $100 \mathrm{mg} / \mathrm{L}$, minyak dan lemak $15 \mathrm{mg} / \mathrm{L}$ serta NH3-N $25 \mathrm{mg} / \mathrm{L}$. Berdasarhan data tersebut maka diperlukan suatu pengolahan sehingga effluent yang dihasilkan memenuhi Pergub Jatim No. 72 Tahun 2013.

Teknologi pengolahan limbah cair dengan beban organik tinggi dapat dilakukan dengan biofilter. Biofilter merupakan salah satu jenis teknologi pengolahan limbah secara biologis dengan menumbuhkan dan mengembangbiakkan mikroba pada suatu media filter sehingga membentuk lapisan biofilm. Beban pencemar zat organik akan didegradasi oleh mikroorganisme yang terdapat dalam biofilm tersebut. Pengolahan dengan biofilter anaerob dapat diaplikasikan untuk treatment dengan beban pencemar yang tinggi (Sugito, dkk 2016). Pengolahan air limbah dengan biofilter anaerob menggunakan media bioball mampu menurunkan kandungan COD sebesar 97\% (Sugito dan Binawati, 2015).

Proses pengolahan air limbah dengan proses biofilter dilakukan dengan cara mengalirkan air limbah ke dalam reaktor biologis yang telah diisi dengan media penyangga untuk pengembangbiakkan mikroorganisme dengan atau tanpa supply aerasi. Aerasi dilakukan untuk memberikan ketersediaan Oksigen, bila dilakukan secara aerob dengan konsentrasi minimal sebesar $1 \mathrm{mg} / \mathrm{l}$. Secara anoxic terjadi bila oksigen yang digunakan bersumber dari senyawa nitrat.

Salah satu faktor yang mempengaruhi proses biofilter adalah beban hidrolik. Beban hidrolik adalah besarnya debit air limbah yang mengalir melewati media tiap satuan luas reaktor. Penggunaan beban hidrolik media sebesar $0,006 \mathrm{~m}^{3} / \mathrm{m}^{2}$ media.hari mampu mereduksi beban COD sebesar 96\% (Kholif dan Hermana, 2013).

Penelitian removal COD dan TSS limbah cair RPA menggunakan sistem biofilter anaerob dilakukan sebagai alternatif pengolahan limbah cair industri RPA Tujuan dalam penelitian ini adalah untuk mengkaji waktu tinggal dan konsentrasi inflent yang bervariasi terhadap efisiensi proses dalam pengolahan menggunakan biofilter. Variabel yang ditetapkan dalam penelitian ini adalah berdasarkan variasi waktu tinggal dan konsentrasi influent. Waktu tinggal merupakan waktu kontak air limbah dengan biofilm. Menurut Parasmita (2012), waktu tinggal air limbah di dalam reaktor biofilter memberikan pengaruh terhadap penurunan konsentrasi zat organik dan TSS. Manfaat dari penelitian ini adalah untuk memberikan rekomendasi agar para pelaku bisnis RPA melakukan pengolahan air limbah yang dihasilkan. Implementasi pemanfaatan reaktor biofilter dapat dilakukan dengan memanfaatkan bahan-bahan yang murah dan mudah diperoleh. Semakin lama 
waktu tinggal air limbah di dalam reaktor membuat efluen yang dihasilkan semakin baik karena proses degradasi bahan organik terjadi secara optimal. Waktu tinggal air limbah dalam reaktor selama 7 jam mampu mendegradasi COD dan TSS sampai dengan efisiensi sebesar $40 \%$.

\section{METODE}

Pada penelitian ini diuji sejauh mana pengaruh waktu tinggal terhadap penyisihanan konsentrasi COD dan TSS pada air limbah industri RPA. Penelitian ini dilakukan secara eksperimen dengan sistem biofilter anaerob tercelup aliran upflow. Media biofilter yang digunakan adalah media bioball. Jenis bioball yang dipilih berbentuk bola dengan kriteria diameter 3,5 $\mathrm{cm}$, warna hitam, bahan termoplastik. Penggunaan bioball didasarkan pada keunggulan media ini yang memiliki luas permukaan spesifik yang besar sehingga pertumbuhan mikroorganisme terjadi secara maksimal. Analisis awal air limbah RPA dilakukan untuk mengetahui konsentrasi awal COD, TSS, pH yang terkandung dalam limbah cair RPA.

Variasi waktu tinggal yang ditetapkan dalam penelitian ini yakni 2 jam, 4 jam, dan 7 jam, dengan konsentrasi influen yaitu tanpa pengenceran, pengenceran (1:2), dan pengenceran (1:3). Variabel terikat yang diuji yaitu kualitas air limbah terolah secara kimiawi yaitu parameter COD, dan TSS. Pemilihan parameter utama COD didasarkan pada kandungan yang sangat tinggi dalam air limbah RPA.

Alat utama yang digunakan dalam penelitian adalah reaktor biofilter anaerob yang terbuat dari kaca dengan ketebalan 5 mm (Gambar 1). Dalam penelitian ini menggunakan 3 reaktor untuk variasi waktu tinggal yang berbeda. Reaktor 1 bervolume $0,002 \mathrm{~m}^{3}$, reaktor 2 bervolume $0,004 \mathrm{~m}^{3}$ dan reaktor 3 bervolume 0,007 $\mathrm{m}^{3}$. Media bioball terletak pada bagian tengah reaktor menempati $40 \%$ volume reaktor. Bahan yang digunakan adalah limbah cair RPA cucian kedua yag diperoleh dari daerah Kedurus Surabaya dan air bersih untuk pengnceran.

Bak penampung limpahan menggunakan bak plastik 50 L. Fungsi bak penampung limpahan ini untuk menampung air limbah RPA serta menyamakan karakteristik air limbah yang akan diolah dalam biofilter. Air limbah yang berasal dari penampungan limpahan dialirkan ke bak penampung influent. Bak penampung influent terbuat dari plastik yang berukuran 25 L. Air limbah dari bak penampung influent dialirkan secara upfllow menuju reaktor 1, 2, 3. Masing-masing saluran menuju reaktor dipasang stopkran, dengan tujuan mengatur debit yang mengalir, dimana debit air limbah dikondisikan dengan debit $0,024 \mathrm{~m}^{3} / \mathrm{jam}$.

Analisis yang dilakukan dalam pengamatan ini adalah parameter COD dan TSS dengan menggunakan prosedur Standard Methods. Perhitungan efisiensi dapat dihitung dengan perbandingan influent dan effluent yang dinyatakan dalam persentase.

Perhitungan efisiensi dihitung dengan rumus:

Efisiensi (E) $=\frac{\text { influent-effluent } \times 100 \%}{\text { influent }}$

Data penelitian yang diperoleh akan dianalisis menggunakan grafik untuk mengkaji efisiensi penyisihan COD dan TSS setelah pengolahan. 


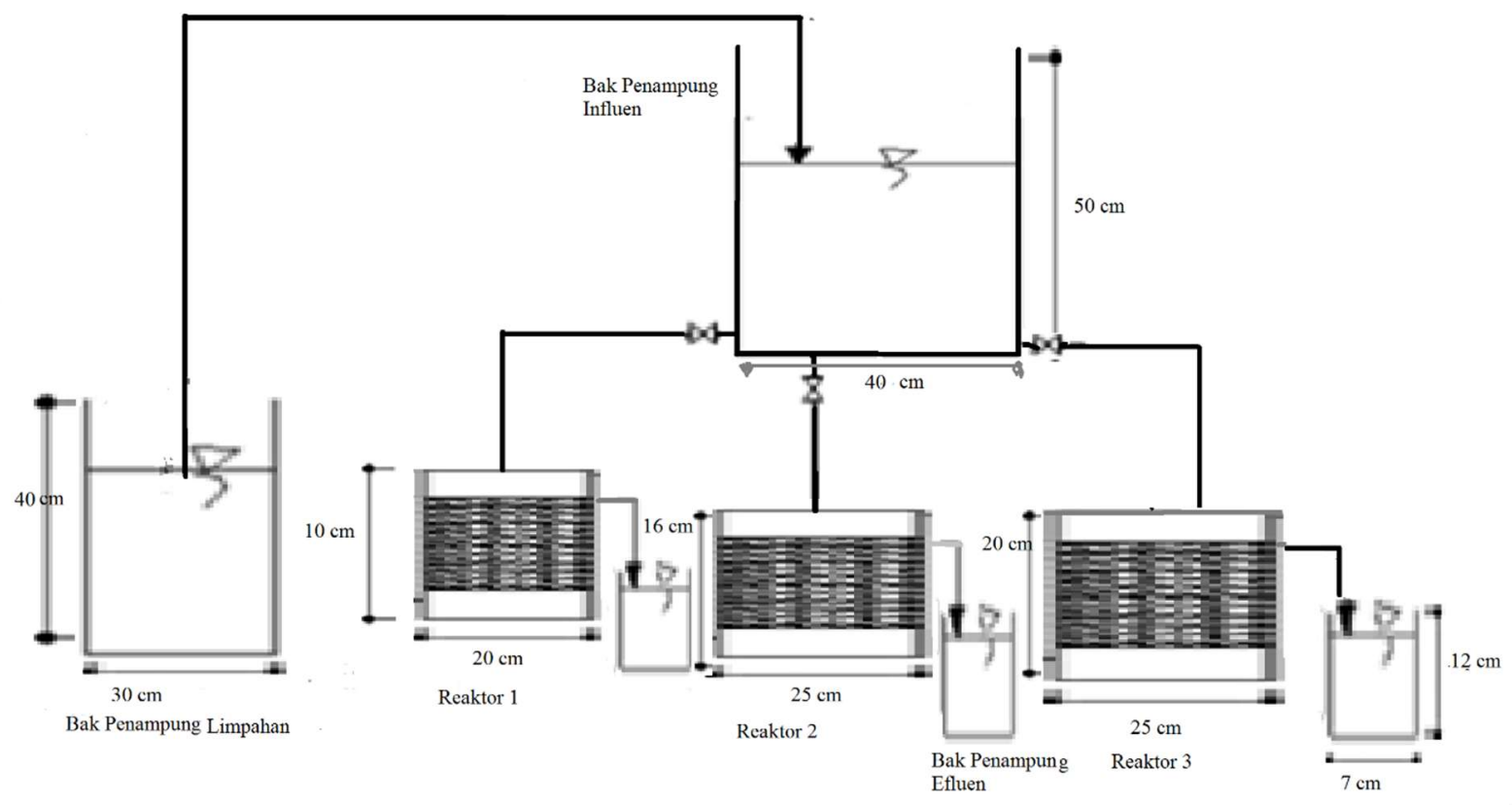

Gambar 1. Reaktor Biofilter Anaerob

\section{HASIL DAN PEMBAHASAN}

\section{a. Analisis Pendahuluan}

Analisis pendahuluan ini bertujuan untuk mengetahui konsentrasi awal COD dan TSS yang akan diolah. Melalui analisis pendahuluan ini maka akan diketahui konsentrasi COD dan TSS dalam air limbah tersebut memenuhi baku mutu atau tidak sehingga layak dilakukan pengolahan. Uji parameter analisis pendahuluan dilakukan pada air limbah pencucian ayam pertama dan kedua pada industri rumah potong ayam (RPA). Hasil analisis parameter awal seperti Gambar 2.

Gambar 2 menunjukkan kandungan beban pencemar pada air limbah pencucian kedua lebih tinggi dibandingkan dengan beban pencemar pada air limbah pencucian pertama. Bedasarkan hasil tersebut, maka perlu dilakukan pengolahan air limbah RPA pencucian kedua. Melalui proses biofilter maka beban pencemar zat organik (COD) yang tidak memenuhi baku mutu menjadi lebih kecil atau bahkan memenuhi baku mutu yang telah ditetapkan.

\section{b. Seeding dan Aklimatisasi}

Sebelum digunakan untuk pengamatan pada media bioball, terlebih dahulu dilakukan proses seeding dan aklimatisasi. Menurut Yahya (2010), tujuan dilakukan seeding selain untuk membenihkan mikroorganisme supaya media mampu melakukan oksidasi pada zat pencemar organik pada air limbah tersebut agar dikondisikan beradaptasinya dengan lingkungan awal tempat berkembangbiaknya mikroorganisme yang akan diujikan di reaktor. Seeding dilakukan untuk membentuk biofilm pada media bioball. Seeding dilakukan dengan cara mengambil air limbah RPA, selanjutnya dimasukkan ke dalam reaktor bersama dengan media bioball. 


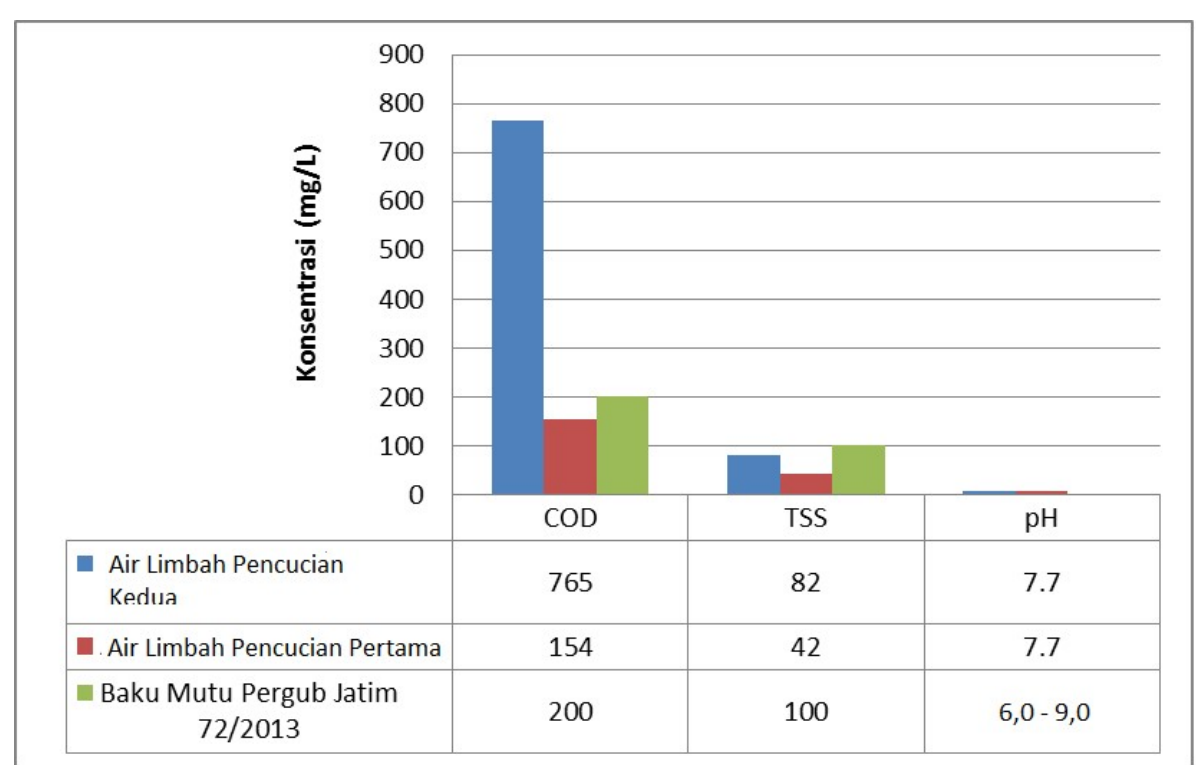

Gambar 2. Hasil Analisis Pendahuluan Air Limbah RPA

Aklimatisasi dilakukan untuk mendapatkan suatu kultur yang baik dan mikroorganisme yang mampu beradaptasi dengan air limbah. Menurut Yahya (2010) seeding dan aklimatisai ini dilakukan selama 2 minggu, sedangkan menurut Al Kholif (2013), seeding dan aklimatisasi prosesnya berlangsung selama 10 hari untuk media bioball dan 12 hari untuk media koral. Perbedaan waktu seeding dan aklimatisasi disebabkan perbedaan media serta jenis limbah yang digunakan.
Lamanya seeding dan aklimatisasi bertujuan agar tepat dengan waktu proses pematangan biofilm tahap akhir, mikroba siap untuk menyebar dan berkolonisasi di tempat lain, sehingga diperoleh biofilm dalam kondisi steady state pada limbah. Untuk mengetahui kondisi steady state pada air limbah, dilakukan uji permanganat. Gambar 3 merupakan hasil analisis nilai permanganat air limbah rumah RPA selama 27 hari.

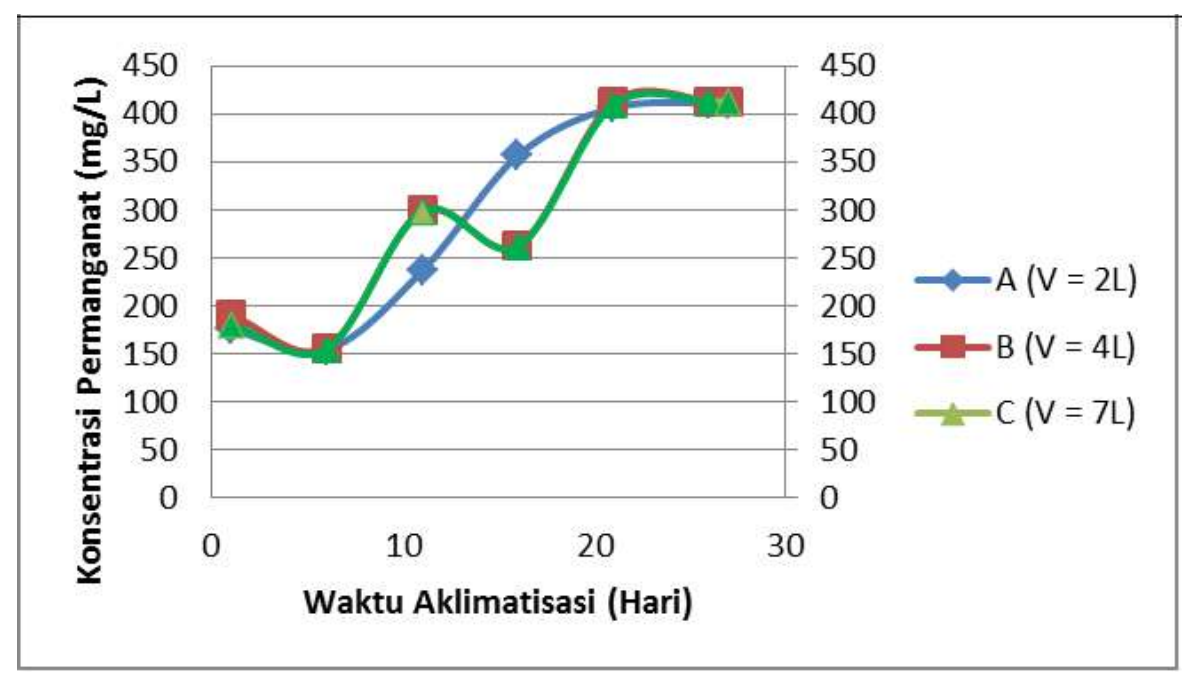

Gambar 3.Grafik Konsentrasi Permanganat 
Gambar 3. menunjukkan proses seeding dan aklimatisasi yang terjadi selama 27 hari. Penentuan waktu seeding dan aklimatisasi dalam kurun waktu 27 hari karena konsentrasi permanganat mulai stabil setelah hari ke 21. Jangka waktu pelaksanaan sampling yang dilakukan 5 hari sekali mengakibatkan kondisi steady state pada reaktor diketahui antara hari ke 21 hingga 26. Setelah kondisi pertumbuhan mikroorganisme stabil maka dapat dilakukan pengambilan sampel untukmenguji parameter COD dan TSS.

\section{c. Analisis Data Konsentrasi Sebelum dan Sesudah Treatment}

Hasil pengamatan ini dianalisis secara deskriptif dengan menggunakan tabel. Adanya beda penurunan nilai parameter uji, menunjukkan tingkat efektivitas yang terjadi selama treatment. Tabel analisis data mecakup konsentrasi COD dan TSS selama treatment. Tabel 1 dan tabel 2 berikut adalah penurunan konsentrasi COD dan TSS sebelum dan setelah treatment menggunakan sistem biofilter anaerob.

Angka COD menunjukkan jumlah oksigen yang diperlukan agar bahan organik yang terdapat dalam limbah cair dapat teroksidasi secara kimia baik yang dapat didegradasi oleh mikroorganime maupun yang sulit didegradasi oleh mikroorganisme. Tingginya angka COD menyebabkan penurunan konsentrasi Oksigen dalam air. Metcalf dan Eddy (2004) menyatakan bahwa oksigen terlarut dalam reaktor melekat diam terendam harus dijaga antara $2-4 \mathrm{mg} / \mathrm{L}$.

Tabel 1. Konsentrasi COD Sebelum dan Setelah Treatment dengan Biofilter Anaerob

\begin{tabular}{cccccc}
\hline & & \multicolumn{4}{c}{ Konsentrasi COD } \\
\cline { 3 - 6 } No & Perlakuan & Influen & \multicolumn{3}{c}{ Effluen (mg/L) } \\
\cline { 3 - 6 } & & $(\mathrm{mg} / \mathrm{L})$ & $\mathrm{Td}=2$ jam & $\mathrm{Td}=4$ jam & $\mathrm{Td}=7$ jam \\
\hline 1 & Variasi 1 & 733,5 & 576,5 & 509,8 & 439,4 \\
2 & Variasi 2 & 388,0 & 309,6 & 268,6 & 222,2 \\
3 & Variasi 3 & 247,6 & 200,1 & 172,6 & 154,8 \\
\hline
\end{tabular}

Tabel 2. Konsentrasi TSS Sebelum dan Setelah Treatment dengan Biofilter Anaerob

\begin{tabular}{cccccc}
\hline & & \multicolumn{4}{c}{ Konsentrasi TSS } \\
\cline { 3 - 6 } No & Perlakuan & \begin{tabular}{c} 
Influen \\
\cline { 3 - 5 }
\end{tabular} & & \multicolumn{3}{c}{ Effluen $(\mathrm{mg} / \mathrm{L})$} \\
\hline 1 & Variasi 1 & 88,4 & 70,5 & 63,1 & 52,5 \\
2 & Variasi 2 & 70,2 & 58,4 & 46,9 & 41,8 \\
3 & Variasi 3 & 54 & 42,2 & 36,2 & 34 \\
\hline
\end{tabular}

Berdasarkan Tabel 1 terlihat bahwa terjadi penurunan konsentrasi COD pada reaktor. Menurut Pergub Jatim No 72, Tahun 2013 untuk baku mutu air limbah rumah potong hewan, standar kandungan COD sebesar $200 \mathrm{mg} / \mathrm{L}$, dan $100 \mathrm{mg} / \mathrm{L}$ untuk TSS. Dalam penelitian ini, kandungan COD pada influen variasi 1 , variasi 2 , dan variasi 3 adalah berturut turut $733,5 \mathrm{mg} / \mathrm{L} ; 388 \mathrm{mg} / \mathrm{L}$; dan $247,6 \mathrm{mg} / \mathrm{L}$ sehingga melebihi baku mutu yang ditetapkan. Sesuai dengan hasil uji yang dilakukan bahwa dengan variasi waktu tinggal yang berbeda-beda ( 2 jam, 4 jam, 7 jam) konsentrasi COD mengalami penurunan. Pada setiap reaktor terlihat bahwa terjadi penurunan konsentrasi COD. Penurunan yang cukup signifikan terjadi pada waktu tinggal 7 jam pada variasi 2 , yaitu dari konsentrasi COD influen 388 $\mathrm{mg} / \mathrm{L}$ menjadi $222,2 \mathrm{mg} / \mathrm{L}$ pada effluen reaktor. Penurunan konsentrasi COD ini penting agar kandungan zat organik yang akan dibuang ke badan air tidak terlalu tinggi.

TSS atau zat total padat tersuspensi diklasifikasikan menjadi zat padat dan melayang yang bersifat organik dan zat 
padat yang terendap yang dapat bersifat organik maupun anorganik (Suroso, 2012) . Berdasarkan Tabel 2 konsentrasi TSS pada influen sudah memenuhi standard baku mutu pergub jatim No 72, Tahun 2013. Efektifnya reaktor biofilter anaerob ini dalam mereduksi TSS dibuktikan dengan besarnya tingkat penurunan yang terjadi.

\section{d. Efisiensi Penyisihan COD dan TSS}

Berikut ini adalah grafik efisiensi penyisihan COD dan TSS, seperti yang tersaji pada Gambar 4 dan Gambar 5.

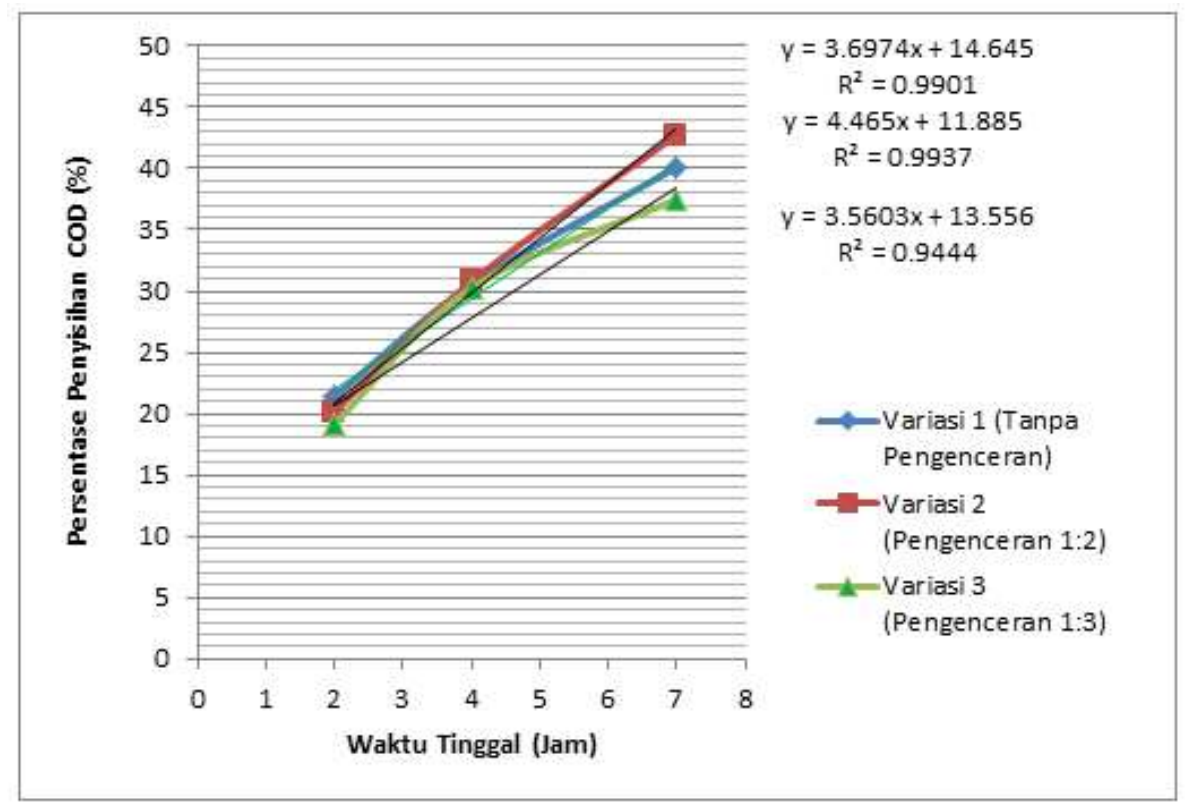

Gambar 4. Grafik Efisiensi Penyisihan COD

Gambar 4 menunjukkan gambaran efisiensi penyisihan COD yang dinyatakan dalam persentase. Efisiensi penyisihan konsentrasi COD menggunakan biofilter anaerob media bioball terlihat mengalami peningkatan terhadap semua variasi. Untuk mengetahui optimalnya efisiensi penurunan terjadi pada waktu tinggal maka dibuat grafik persamaan aritmatik tiap variasi. Persamaan untuk efisiensi penurunan konsentrasi COD variasi 1 adalah : $\mathrm{y}=$ $3,6974 \mathrm{x}+14,645$, dimana $\mathrm{x}=$ waktu tinggal di dalam reaktor (jam) dan $\mathrm{y}=$ konsentrasi COD $(\mathrm{mg} / \mathrm{L})$. Persamaan tersebut memiliki nilai $\mathrm{r}$ sebesar 0,9901 sehingga derajat keyakinannya 99,01\%. Persamaan untuk efisiensi penurunan konsentrasi COD variasi 2 adalah sebagai berikut: $\mathrm{y}=4,465 \mathrm{x}+11,885$. Persamaan tersebut memiliki nilai $r$ sebesar 0,9937 sehingga derajat keyakinannya 99,37\%. Sedangkan persamaan untuk efisiensi penurunan konsentrasi COD variasi 3 adalah sebagai berikut: $\mathrm{y}=3,5603 \mathrm{x}+$ 13,556 dengan nilai 0.9444 , sehingga derajat keyakinannya $94,44 \%$.
Pada Gambar 4 menunjukkan bahwa semakin lama waktu tinggalnya di dalam reaktor maka semakin efektif penurunan konsentrasi COD. Efisiensi tertinggi dicapai pada waktu tinggal 7 jam. Efisiensi penurunan konsentrasi COD yang terjadi sebesar $40,10 \%, 42,73 \%$, dan $37,48 \%$ pada variasi 1, 2, dan 3. Bila dibandingkan dengan penelitian Sugito dan Binawati (2015), maka efisiensi reduksi COD dalam penelitian ini masih lebih rendah. Hal ini dimungkinkan karena dimensi reaktor dalam penelitian ini yang kecil. Dimensi reaktor yang besar sesuai dengan beban hidrolik yang ditetapkan akan memberikan ruang yang cukup tersedia bagi media untuk menumbuhkan mikroorganisme membentuk biofilm. Menurut Al Kholif dan Hermana (2013) pengaruh waktu tinggal dapat memberikan kesempatan bagi organisme untuk tumbuh dan berkembang secara efektif dalam mendegradasi bahan organik. 


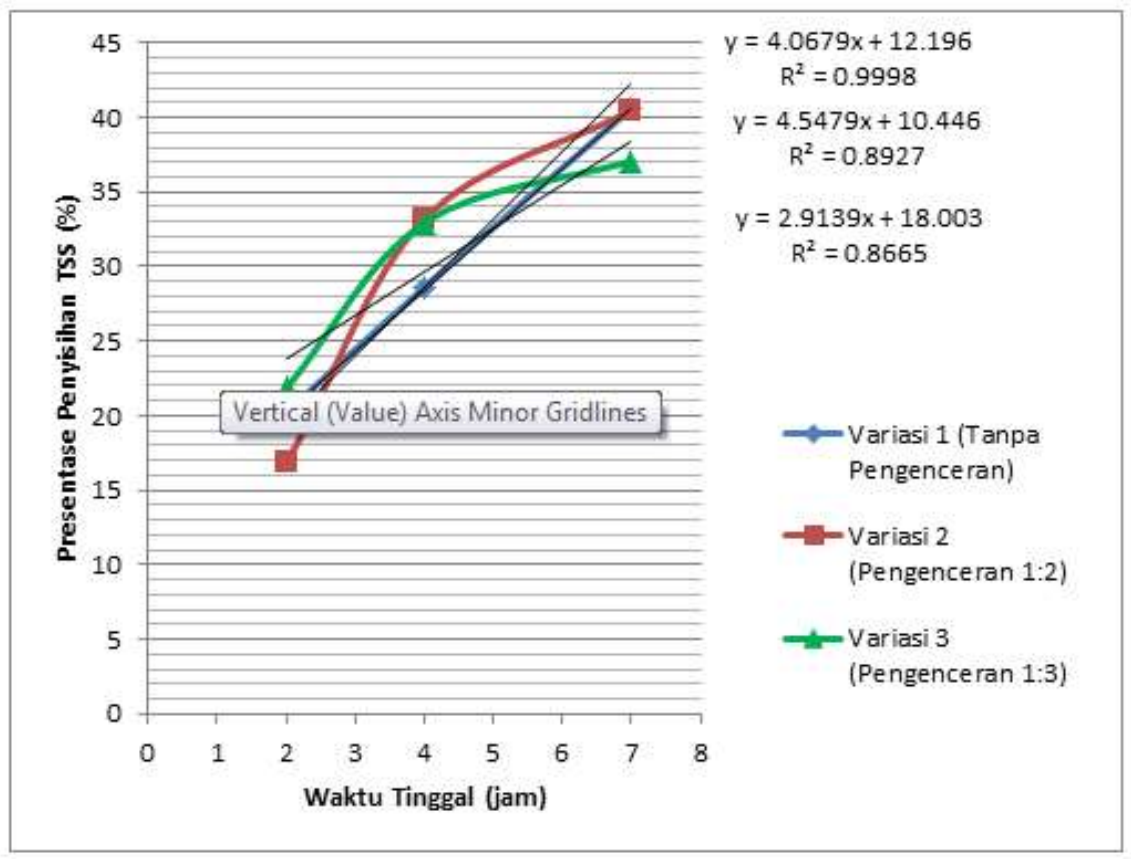

Gambar 5. Grafik Efisiensi Penyisihan TSS

Gambar 5, adalah gambaran efektivitas penurunan TSS menggunakan biofilter anaerob media bioball. Untuk mengetahui optimalnya efisiensi penurunan terjadi pada waktu tinggal maka dibuat grafik persamaan aritmatik. Persamaan untuk efisiensi penurunan konsentrasi TSS pada masing-masing variasi adalah sebagai berikut: variasi $1=4,0679 x+12,196 ; y=$ $4.5479 \mathrm{x}+10,446$ pada variasi 2 , dan $\mathrm{y}=$ $2,9139 x+18,003$ pada variasi 3 . Dimana $x$ = waktu tinggal di dalam reaktor (jam) dan $\mathrm{y}=$ konsentrasi TSS $(\mathrm{mg} / \mathrm{L})$. Persamaan tersebut memiliki nilai $r$ yang menunujukkan suatu derajat keyakinan. Jadi derajat keyakinan pada variasi 1 adalah $99,98 \%$, derajat keyakinan pada variasi 2 sebesar $89,27 \%$, serta $86,65 \%$ untuk derajat keyakinan pada variasi 3.

Berdasarkan gambar 5 dapat disimpulkan bahwa semakin lama waktu tinggal di dalam reaktor maka semakin efektif penurunan konsentrasi TSS. Efektifitas tertinggi dicapai saat waktu tinggal 7 jam dengan efisiensi penyisihan 40,61\%. Hal ini disebabkan karena waktu tinggal di dalam reaktor dapat mempengaruhi penurunan kadar parameter TSS, dengan bertambah lamanya waktu tinggal air limbah di dalam reaktor maka kesempatan zat padat terlarut untuk mengendap semakin tinggi. Sehingga pada effluent reaktor mengalami penurunan konsentrasi zat padat terlarut.Kandungan TSS dalam air limbah dalam penelitian ini termasuk kategori rendah, sehingga efisiensi pengemdapannya sudah optimal dibandingkan ketika pada pengolahan dengan influent TSS yang tinggi.

\section{KESIMPULAN}

Lamanya waktu tinggal air limbah di dalam reaktor biofilter anaerob memberikan pengaruh terhadap penyisihan konsentrasi COD dan TSS pada limbah cair RPA. Waktu tinggal yang paling efektif dalam menurunkan kadar COD dan TSS pada limbah cair RPA adalah 7 jam dengan rata-rata efisiensi penyisihan $40 \%$ untuk kadar COD dan rata-rata efisiensi penyisihan 39\% untuk kadar TSS.

Industri RPA dapat menerapkan sistem pengolahan ini untuk buangan limbah cairnya. Namun perlu dikombinasikan dengan treatment pengolahan limbah yang lain agar effluent yang dihasilkan memenuhi PERGUB JATIM No.72 Tahun 2013. Selain itu juga perlu dilakukan pengamatan yang serupa dengan menggunakan reaktor biofilter anaerob tercelup media bioball dengan melihat lamanya waktu tinggal limbah cair RPA di dalam reaktor yang lebih lama agar kadar COD sampai pada level baku mutu yang telah ditetapkan, sehingga dapat diketahui keefektifan waktu tinggal serta 
jenis pengolahan yang digunakan untuk menurunkan kadar parameter pencemar limbah cair RPA sesuai dengan baku mutu yang telah ditetapkan.

\section{Ucapan Terima Kasih}

Penelitian ini mendapat dukungan dari dekan dan kaprodi. Penulis juga mengucapkan terima kasih kepada Badan Lingkungan Hidup Surabaya, dan Mohamad Riski yang telah banyak membantu selama pengamatan, serta segenap pihak yang telah ikut andil dalam proses penyelesaian penelitian ini yang tidak dapat penulis sebutkan satu per satu.

\section{DAFTAR PUSTAKA}

Al Kholif M.; Hermana J. 2013. The Wastewater Treatment of Chicken Slaughterhouse by Using Al Kholif, M. 2013. Aplikasi Biofilter Anaerob Pada Air Limbah cucian dari Rumah Potong Ayam. Thesis (2013). http://digilib.its.ac.id/ITS-Master33003140000472/28900 (Tanggal mengunduh : 16Agustus 2016)

Al Kholif, M. 2015, Pengaruh Penggunaan Media Dalam Menurunkan Kandungan Amonia Pada Limbah Cair Rumah Potong Ayam (RPA) Dengan Sistem Biofilter Anaerob, Jurnal Teknik Waktu, Vol: B (01) Januari 2015-ISSN 1412-1867:13-18, Universitas PGRI Adibuana, Surabaya.

Al Kholif, M. dan Hermana. 2013. The Wastewater Treatment of Chicken Slaughterhouse by Using Submerged up flow Anaerobic Biofilter. Proceeding International Seminar on Enviromental Engineering (ISEE, 2013) hal. 484-490.

Metcalf \& Eddy, 2004. Wastewater Enginering Treatment And Reuse, Fourth Edition, MegrawHill Inc, New York

Parasmita B. N., W. Oktiawan, M. Hadiwidodo, 2012, Studi pengaruh waktu tinggal terhadap penyisihan $\mathrm{BOD}_{5}, \mathrm{COD}$, dan TSS Lindi menggunakan biofilter aerob-anaerob, Jurnal Presipitasi, Universitas Diponegoro, Semarang.

PERGUB JATIM Nomor 72 Tahun 2013 tentang baku mutu Limbah cair. BLH Propinsi Jawa Timur, Surabaya.

Said, N. I. dan Firly. 2005, Uji Performance Biofilter Anaerobic Unggun Tetap Menggunakan Media Bofilter Sarang Tawon Untuk Pengolahan Air Limbah Rumah Potong Ayam, JAI. 1 (3) : 289-294, BPPT, Jakarta.

Said, N. I. 2005, Pengolahan Air Limbah Industri Kecil Tekstil Dengan Proses Biofilter Anaerob-Aerob Tercelup Menggunakan Media Plastik Sarang Tawon, Jurnal Teknologi Lingkungan. 2 (2) : 124-135, BPPT, Jakarta.

Singgih M. L dan M. Kariana, 2008, Peningkatan Produktifitas dan Kinerja Lingkungan Dengan Pendekatan Green Productivity Pada Rumah Pemotongan Ayam XX, Purifikasi :Jurnal Manajemen Lingkungan, . 9 (2) :1-2, FTSP-ITS \& Ikatan Ahli Teknik Penyehatan \& Teknik Lingkungan Indonesia, Surabaya.

Sugito dan Binawati, 2015, Pengembangan Reaktor Biofilter Anaerob Untuk Mengolah Limbah Cair Industri RPA. Laporan Penelitian Dikti Hibah Bersaing Tahun 2015, FTSP-UNIPA, Surabaya.

Sugito, Binawati dan Al Kholif, M. 2016. The Effect of BOD Concentrate Influent to Remove Pollutant Lood in Wastewater of a chicken Slaugterhouse. ARPN Journal of Engineering and Applied Sciences. Vol 11: 3519-3524.

Suroso, Erdi, 2011. Model Proses Produksi Industri Tapioka Ramah Lingkungan Berbasis Produksi Bersih, Jurnal Teknik Kimia, Institut Penelitian Bandung, Bandung

Yahya, F., 2010. Jurnal Studi Pengolahan Air Limbah Domestik Dengan Biofilter Aerasi menggunakan Media Bioball dan Enceng Gondok (Eichornia crassipes), Institut Teknologi Surbaya, Surabaya. 